\title{
Comparison of rapid response impulsivity and choice impulsivity between children with attention-deficit/hyperactivity disorder and normal children
}

\author{
Abbas Bakhshipour ${ }^{1}$, Gholam Reza Chalabianloo², Farnaz Jahanbin ${ }^{3 *}$ \\ 1. Professor in Clinical Psychology, University of Tabriz, Tabriz, Iran \\ 2. Associate Professor in Neuroscience, Azarbaijan Shahid Madani University, Maragheh, Iran \\ 3. MA in General Psychology, University of Tabriz, Tabriz, Iran
}

Recieved: 27 Dec. 2018

Revised: 3 Feb. 2019

Accepted: 8 Apr. 2019

Keywords

Rapid response impulsivity

Choice impulsivity

Attention-deficit/hyperactivity

disorder

Corresponding author

Farnaz Jahanbin, Faculty of Educational Sciences and Psychology, Tabriz University, Emam Khomeini St, 29 Bahman Blvd, Tabriz

Email: Farnazjahanbin@ymail.com

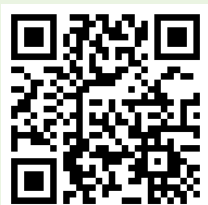

\section{Abstract}

Introduction: Impulsivity is one of the features of attention-deficit/hyperactivity disorder. Rapid response impulsivity and choice impulsivity encompass two different structures of impulsivity, which take place due to the deficiency in response inhibition and inhibition of immediate execution of a strong desire, respectively. Studying the existing differences in these structures between two groups with and without this disorder is clinically crucial. Therefore, the present study aimed to compare the rapid response impulsivity and choice impulsivity between children with attention- deficit/hyperactivity disorder and normal children.

Methods: This research was conducted with a causal-comparative method on 19 children with attention-deficit/hyperactivity disorder and 19 normal children (at the age of 8 to 10 years) who selected, based on the purposive sampling method. The participants were evaluated using Structured Diagnostic Interview, Raven IQ test, and Conners' Parent and Teacher Rating Scales-revised (short form), and they were then grouped. The performance of the groups has determined using the second version of the Continuous Performance Test (CPT-II) and Real-time Discounting Task. Data have been analyzed using multivariate analysis of variance (MANOVA) and SPSS-20 software.

Results: The results obtained from the current research indicated a significant difference between groups in the rapid response impulsivity $(\mathrm{P}<0.017)$, while there is no significant difference between groups in the choice impulsivity $(\mathrm{P}>0.017)$. Based on the obtained results, children with attention-deficit/hyperactivity disorder performed poorly in the rapid response impulsivity task.

Conclusion: According to the results of this research, there is a significant difference in rapid response impulsivity between two groups but there is no significant difference in choice impulsivity between them. Thus, rapid response impulsivity may be more important than choice impulsivity in the attention-deficit/hyperactivity disorder. 
())

\title{
مقايسه تكانشكرى سرعِّ ياسخ و تكانشكرى انتخاب در كودكان مبتلا به اختلال نقص توجه/بيشفعالى و كودكان عادى
}

\author{
(iD" عباس بخشى يور'، غلامرضا جلبيانلو'، فرناز جهان بين
}

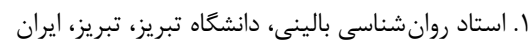

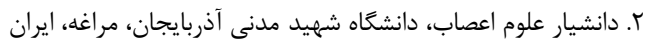

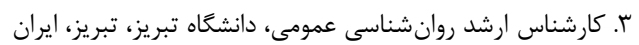

\section{وكيده}

مقدمهاه: تكانشكَى يكى از مشخصهاى اختلال نقص توجه/بيشفعالى است. تكانشكَى سرعت پاسخ و تكانشكرى انتخاب دو ساخت متفاوت تكانشكرى هستند كه به ترتيب در اثر نقص در بازدارى ياسخ و بازدارى اجراى فورى يك ميل قوى خ مى دهند. بررسى تفاوتهاى موجود در اين ساختها بين افراد مبتلا به اين اختلال و افراد فاقد اين اختلال، از لحاظ بالينى حائز اهميت است. بنابراين هدف يُروهش حاضر، مقايسه تكانشَّرى سرعت ياسخ و تكانشَّرى انتخاب در كودكان مبتلا به اختلال نقص توجه/بيشفعالى و كودكان عادى بود. روش كار: اين يروهش على_مقايسهاى بر روى 19 كودى مبتلا به اختلال نقصتوجه/بيشفعالى و 19 كودى عادى (در سنين ^ ثا •ا سال) كه به روش نمونه كيرى هدفمند انتخاب شده بودند، انجام شد. شركت كندكان با استفاده از مصاحبه تشخيصى ساختاريافته، آزمون هوشى ريون و مقياسهاى تجديدنظر شده درجهبندى والد و معلم (فرم كوتاه) مورد سنجش قرار كرفتهاند و سيّ كَروهبندى شدند. عملكرد كروهها با استفاده از نسخه دوم آزمون عملكرد بيوسته و آزمون كاهش ارزش تاخيرى زمان واقعى ارزيابى شد. تحليل دادهها با استفاده از آزمون واريانس حند متغيرى

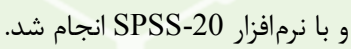

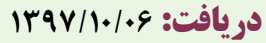

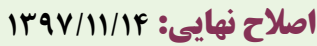

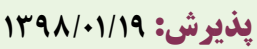

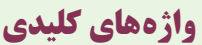
تكانشكرى سرعت ياسخ تكانشكرى انتخاب

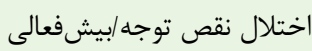

نويسنده مسئول

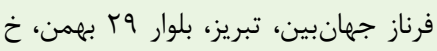

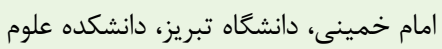
تربيتى و روانشناسى

ايميل:Farnazjahanbin@ymail.com

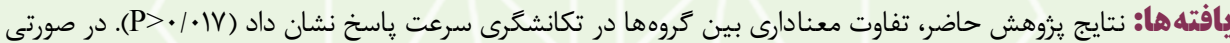

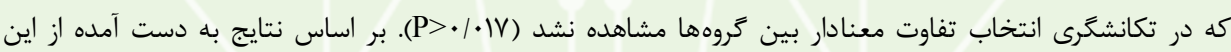
يرؤش، كودكان مبتلا به اختلال نقص توجه/بيشفعالى در تكليف تكانشكرى سرعت ياسخ عملكرد ضعيفترى داشتند. نتيجه كَيرى: بر اساس يافتهاى بروهش حاضر، تفاوت معنادارى در تكانشكَى سرعت ياسخ بين دو كروه، وجود داشت، ولى در تكانشكرى انتخاب بين دو كروه، تفاوت معنادارى وجود نداشت. بنابراين، شايد در اختلال نقص توجه/بيشفعالى، تكانشكَى سرعت پاسخ از اهميت بيشترى نسبت به تكانشكَى انتخاب برخوردار باشد.

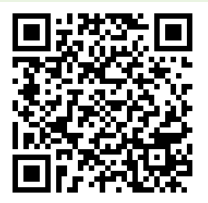

dol doi.org/10.30699/icss.21.4.1

مقلدمه

(Diagnostic and Statistical Manual of Mental متعددى شده است، اختلال نقص توجه/بيشفعالى Disorder) (Attention-deficit/hyperactivity كودكى به شمار مىرود. در ابتدا تصور بر اين بود كه اين اختلال منحصر به دوران كودكى است، اما با بررسىها و يزوهشهاى بيشتر
دوره كودكى به علت سرعت فرآيندهاى رشدى، دورهى تأثيركذارى در زندگى افراد محسوب مى شود. در اين دوره ممكن است كودكان براثر عواملى با مشكلات و اختلالاتى مواجه شوند كه تأثير آن در تمام طول عمر يا برجاست. يكى از اين اختلالات كه در طول ويراست هاى متعدد

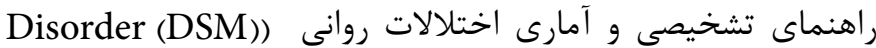


اختلالات شخصيت (به ويزه گروه B)، اعتياد، نقص توجه/بيشفعالى و

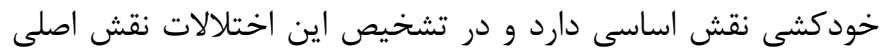
را ايفا مى كند. همآيندى بالا ميان اين اختلالات روان يزشكى بر اين

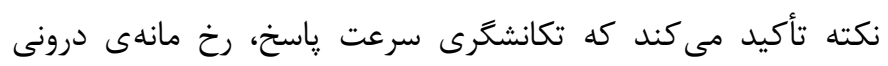
اصلى در بسيارى از اختلالات روان يزشكى است.

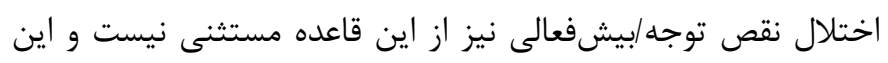

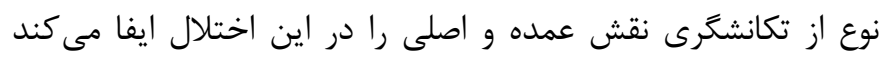

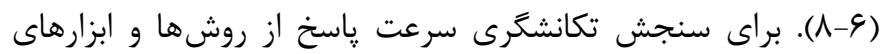
متفاوتى مانند انواع يرسشنامهاو ورش سنجش تجربى (غالبا تكاليف رايانهاى) استفاده شده است. يرسشنامه تكانشكرى Barrat و تكاليف آزمونهاى عملكرد يِيوسته (Continuous Performance Test)، آزمون توقف_نشانه (Stop-signal test) و آزمون Go/No Go test)

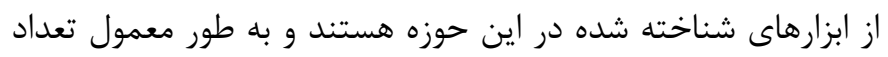

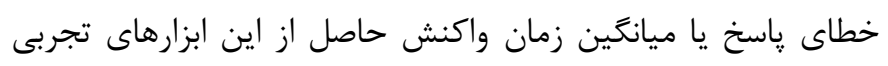

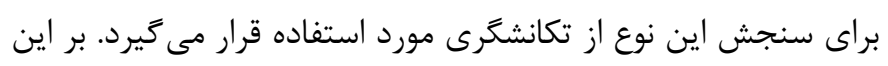

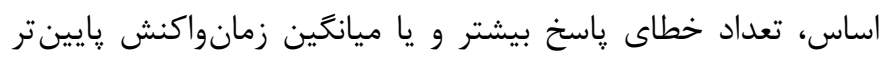

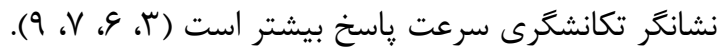
با وجود شواهد نظرى كه از وجود تفاوت در تكانشكرى سرعت پاسخ بين مبتلايان به اختلال نقص توجه/بيشفعالى و جمعيت عادى حمايت مى كند، شواهد يزوهشى متناقضى در رابطه با اين موضوع وجود دارد.

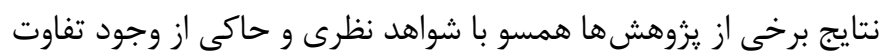

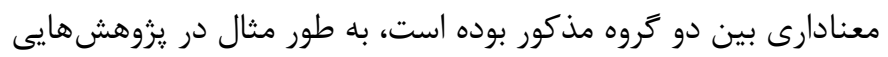

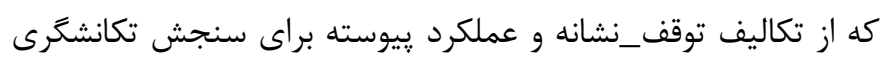

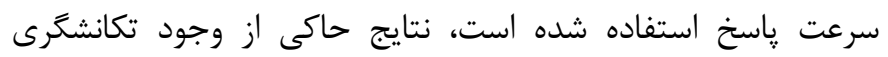

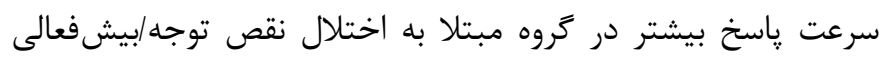
نسبت به كروه عادى است (•(1) (1). در صورتى كه بر اساس نتايج برخى از يزوهشها تفاوت معنادارى بين دو كروه مشاهده نشده است.

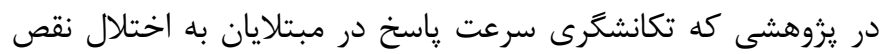
توجه ابيشفعالى (با و بدون وابستكى به كو كائين) و افراد عادى بررسى دانى

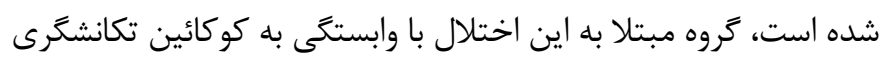

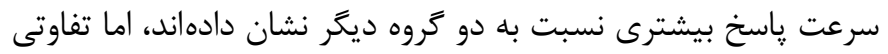

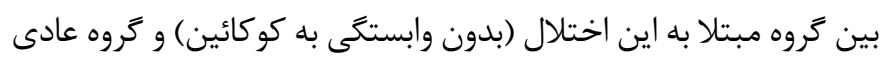

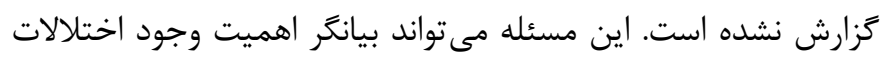

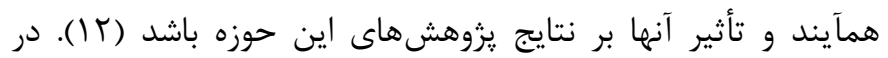

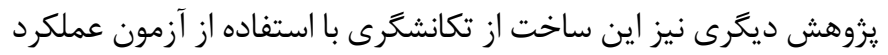
بيوسته بين تروهها ارزيابى و نتايج برخلاف بيشينه نظرى و يزوهشى، حاكى از عدم وجود تفاوت معنادار بين گروهها بود (با ).
در اين زمينه وجود اين اختلال در بزرگسالى نيز تاييد شده است. بر

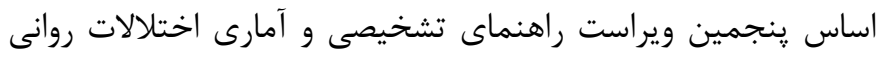

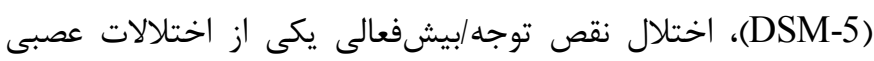

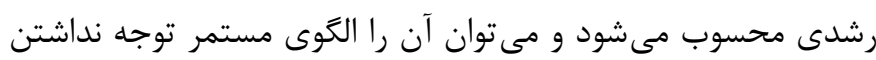

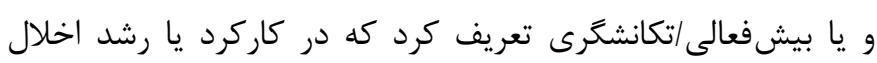

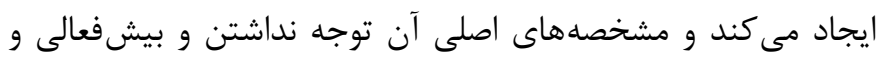
تكانشكَى است. با توجه به تعريف و ملاك هاى تشخيصى اين اختلال، تكانشگرى (Impulsivity) يكى از مشخصههاى اصلى اين اختلال

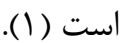

بسيارى از اختلالات روانيزشكى با تكانشكَى در ارتباط هستند.

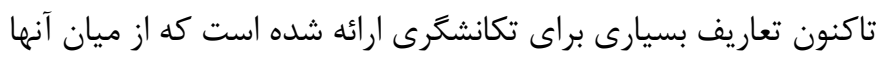

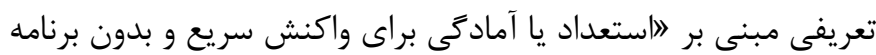

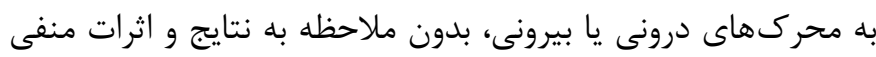

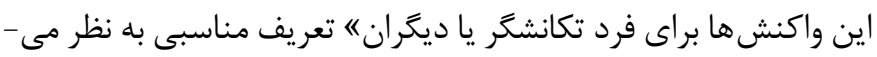

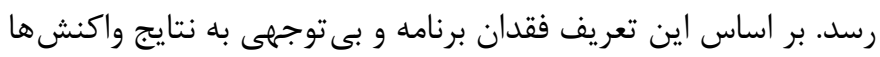
در آينده، دو مشخصهى اصلى تكانشكرى است (T). معمولاً بروهشكَران و درمانكران تكانشكرى را يك ساخت واحد در نظر كرفته و تأكيد آنها بر جنبه سريع بودن واكنشها است. در صورتى كه شواهد حاكى از آن است كه تكانشخرى يك ساخت واحد نيست، بلكه داراى ساختهاى مجزا است (r، זّ). با توجه به ارتباط تكانشكَى با بازدارى، مى توان

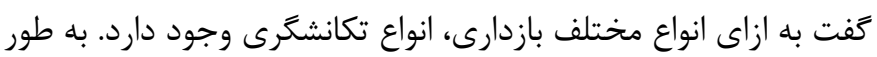

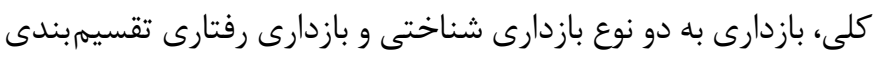

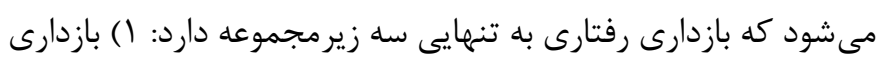

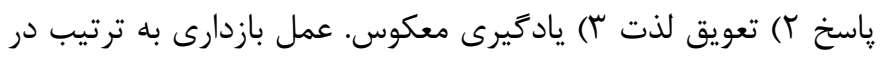

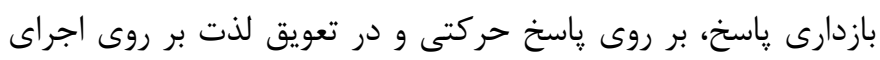
فورى يك ميل قوى و در يادگيرى معكوس بر روى ياسخى كه سابقا تجربلى دريافت پاداش را داشته ولى هم اكنون مورد بازخواست و تنبيه قرار كرفته است، اعمال مى شود. در صورت بروز نقص در هر كدام از اين انواع بازدارى، نوع خاصى از تكانشكرى بروز مى كند (Y).

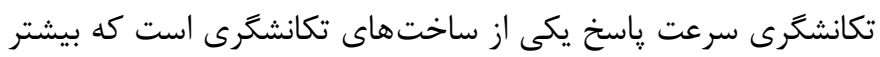

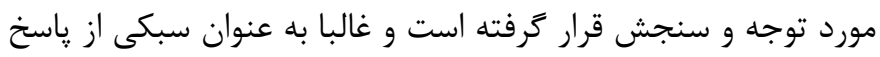

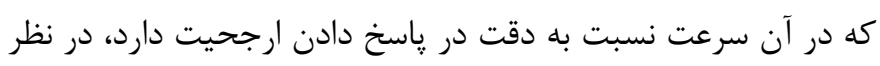

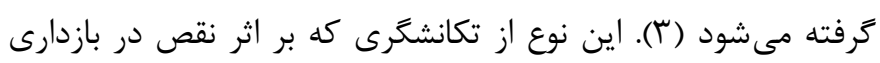

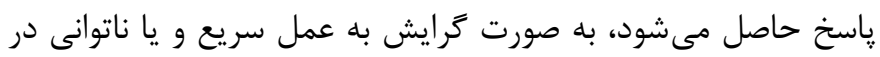
خوددارى از انجام عمل نامتناسب با تقاضا و شرايط محيطى، بازتاب

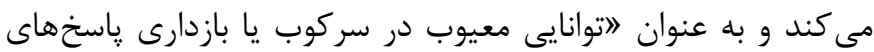
غالب" تعر يف مىشود (ه، ؟). اين نوع از تكانشكَى در اختلالاتى مانند 
اختلالاتى است كه وجود تكانشكرى انتخاب در آنها كزارش شده و

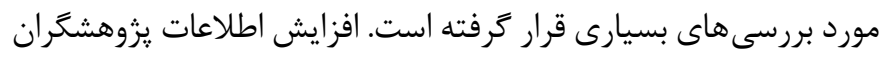

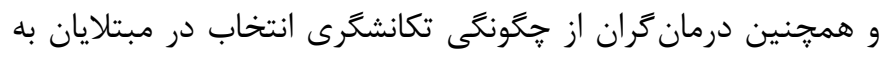

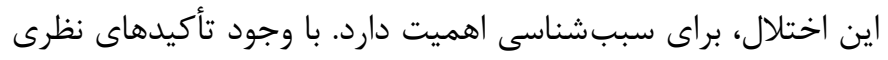

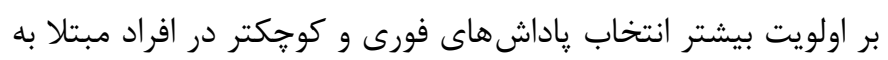

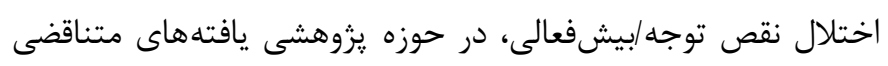

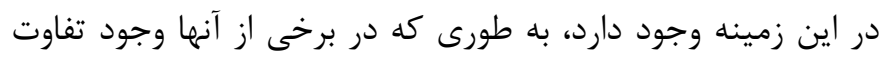

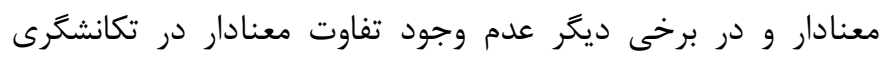

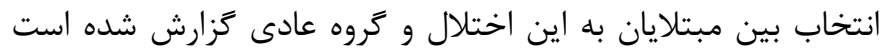
(F ( ). در يزوهشى كه تكليف كاهش ارزش تاخيرى زمان واقعى (ابزار مورد استفاده در يزوهش حاضر) توسط Rosch و Mostofsky ابداع و

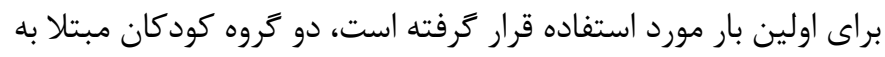

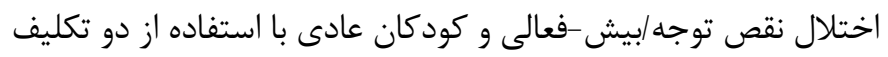
كاهش ارزش تاخيرى (تكليف كلاسيك كاهش ارزش تاخيرى و تكليف

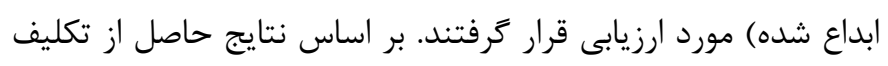

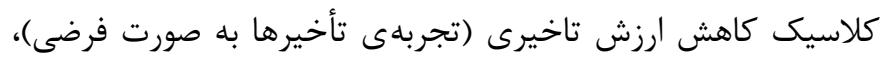

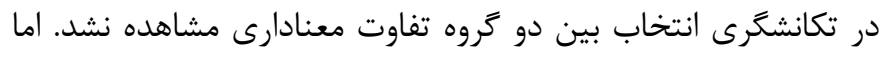

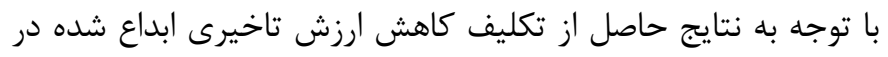

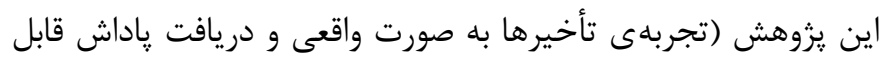

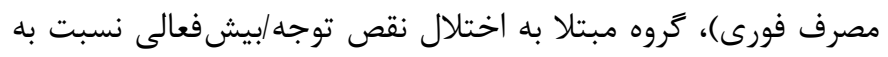

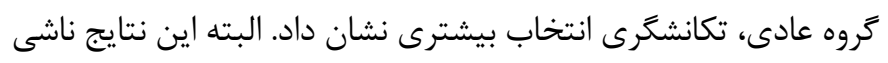

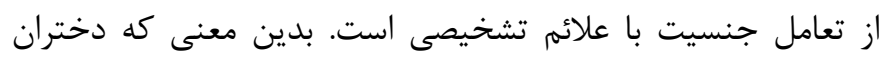

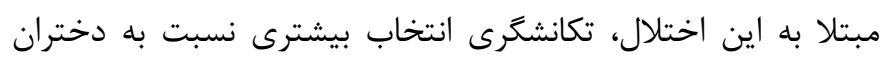

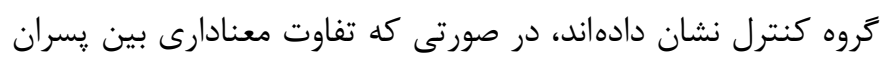

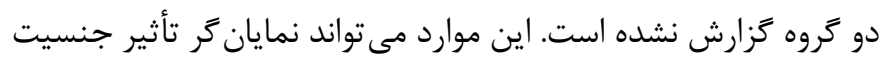

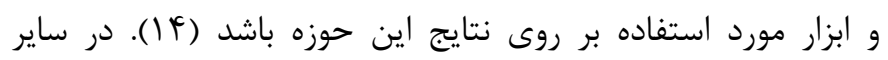

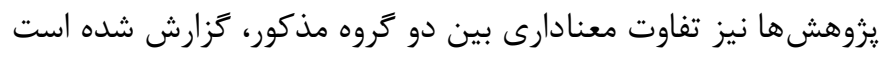

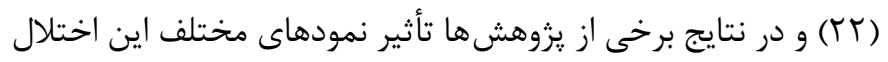

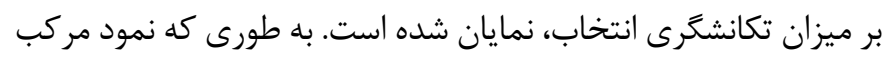

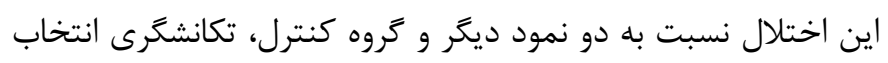

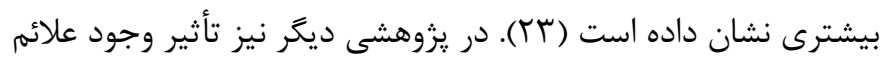

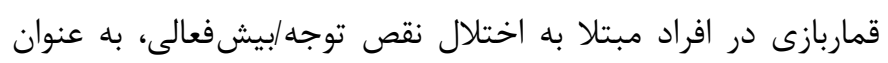
عامل افزايش تكانشخرى انتخاب در اين افراد بررسى شده است (TF (TF).

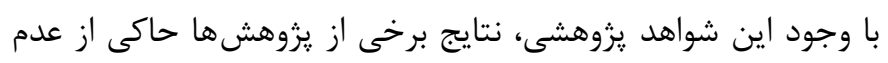

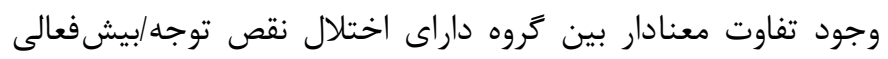

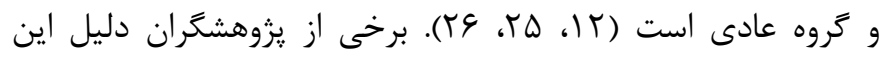

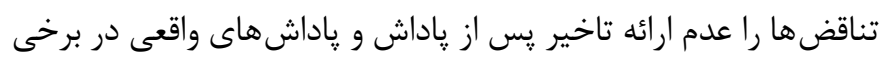

تكانشكرى انتخاب يكى ديكر از ساختهاى تكانشكَى است كه در

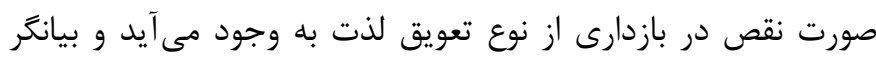

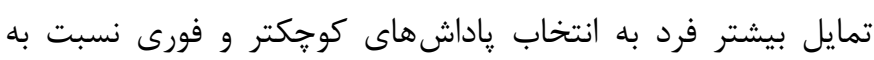

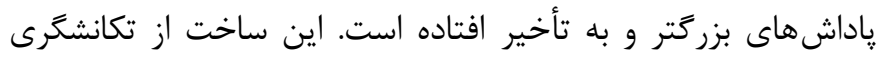

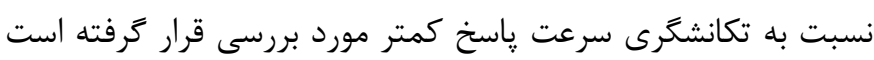

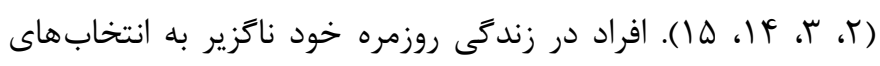

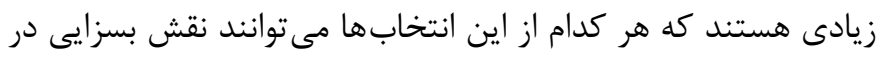

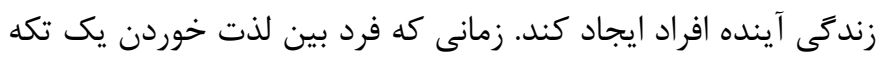

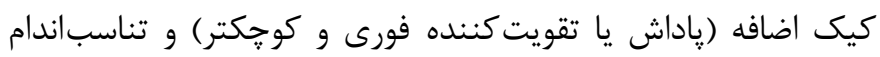

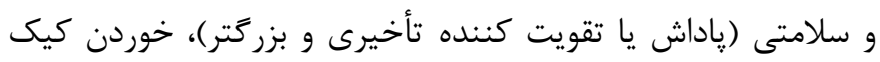

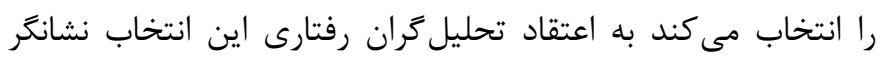

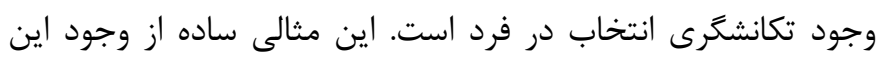

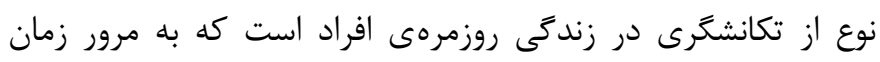

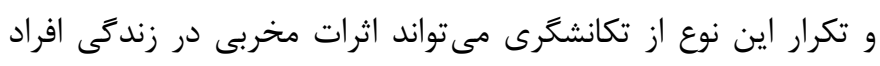

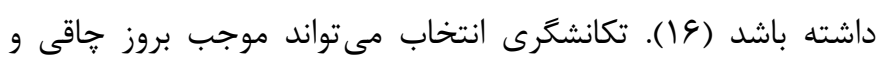

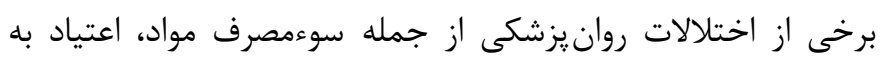

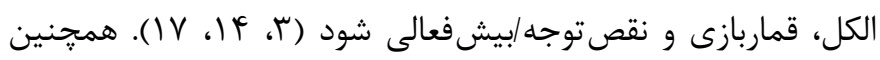
وجود ارتباط بين انواع مختلف جرمهاى قضايى و تكانشكرى انتخاب كزارش شده است (1) (1). روش كاهش ارزش تاخيرى (Delay discounting) يكى از روش هايى (1).

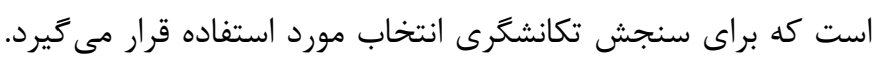
يبش فرض كاهش ارزش تاخيرى اين است كه با افزايش ميزان تاخير

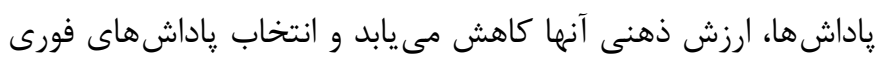

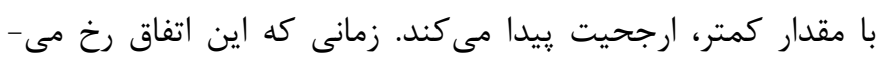

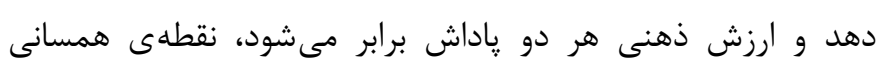

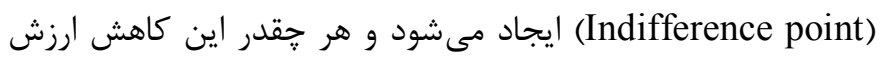

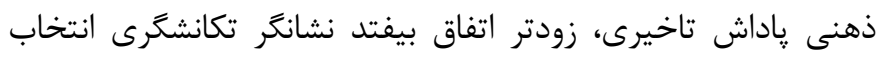

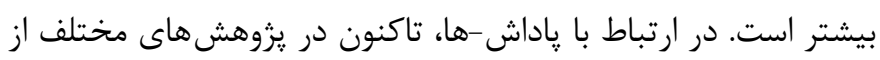

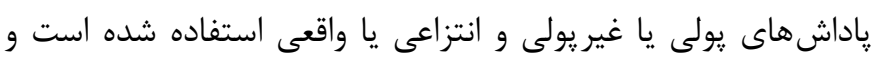

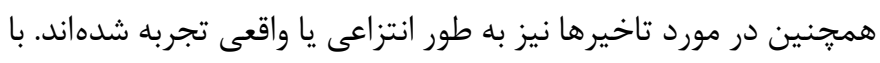

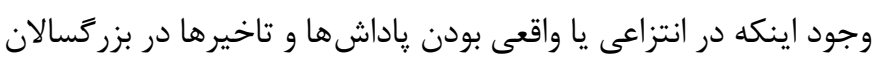

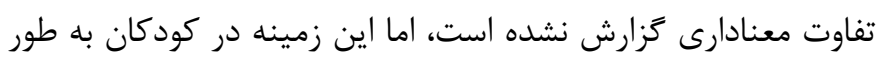

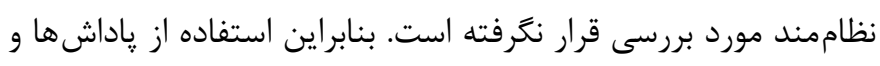

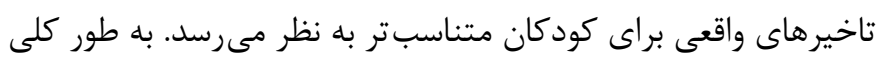
مى توان كفت كه روش كاهش ارزش تاخيرى رويكردى دقيق و كمى كي

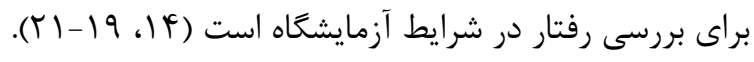

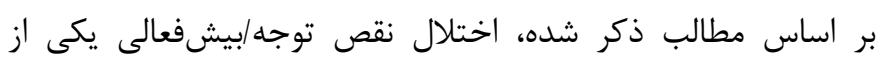


(9 نفر) كروهبندى شدند. ملاكهاى خروج نيز شامل وجود تشخيص عقبماندگى ذهنى و اوتيسم، مصرف دارو و دريافت درمان براى اختلال نقص توجه/بيش فعالى بود. با توجه به ملاكهاى خروج و يا وجود شك دان و ترديد در وضعيت تشخيصى و عدم توانايى ادامه همكارى بعضى

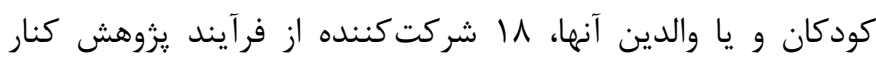
كذاشته شدهاند. در اين يزوهش از مصاحبه تشخيصى ساختاريافته،

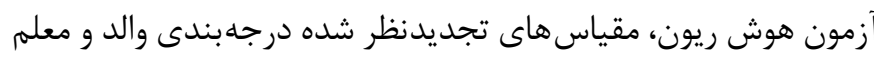

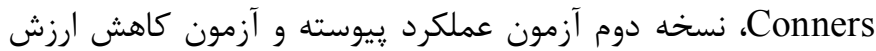
تاخيرى زمان واقعى استفاده شد. مصاحبه تشخيصى ساختاريافته: ملاكهاى تشخيصى اختلال نقص توجه/بيشفعالى بر اساس ويراست קنجمم راهنماى تشخيصى و آمارى

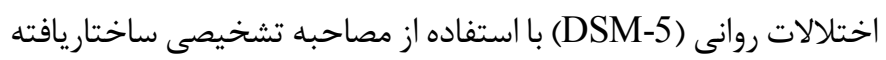
در هر دو گروه مورد بررسى قرار كرفت. بر اساس اين مصاحبه افرادى

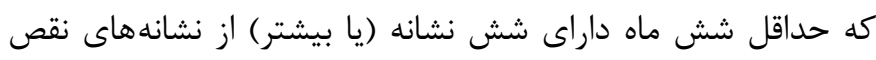

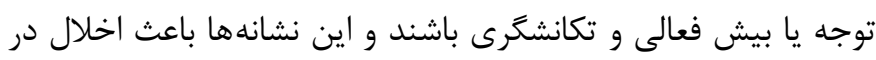

كاركردها شوند، داراى اختلال نقص توجه/بيشفعالى هستند (1). آزمون هوش ريون: در اين يزوهش براى سنجش هوش شركت كنند از نسخهى رايانهاى آزمون هوش ريون استفاده شده است. كودكان

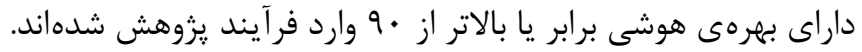
مقياس تجديدنظر شده درجهبندى والد و معلم Conners: براى

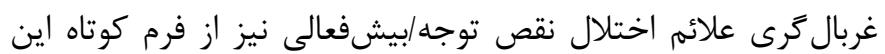

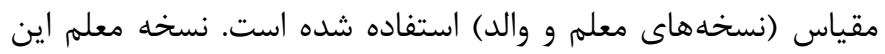

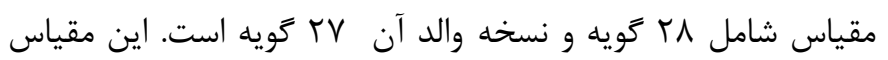

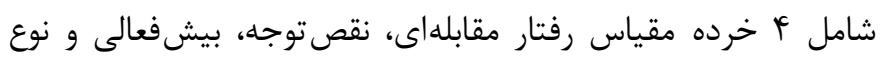

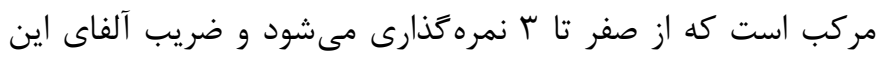

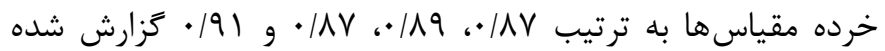
است. نمرههاى برش براى مقياسهاى نقصتوجه، بيشفعالى و نوع

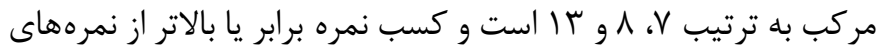
برش نشانكر وجود علائم مذكور در شركت كننده است (TV).

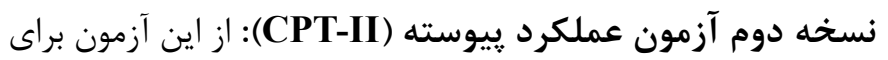

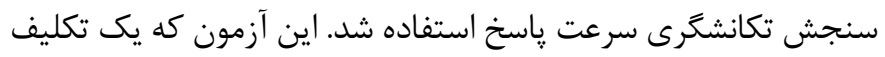

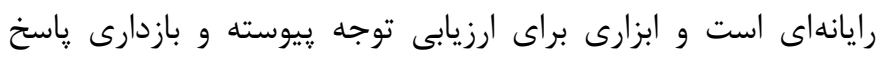

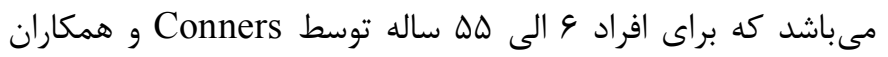
در سال ... P طراحى شده است. نسخه فارسى اين تكليف توسط

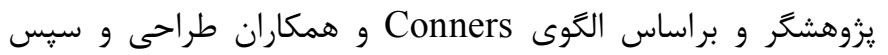
توسط يك عصبشناس تاييد شد، كه در نهايت در اين يزوهش مورد

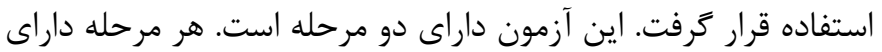

از يزوهش ها ذكر كردهاند (i ) (I). بنابراين با توجه به پيشينه نظرى، دو مشخصهى اصلى تكانشكرى

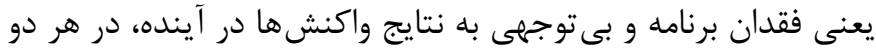

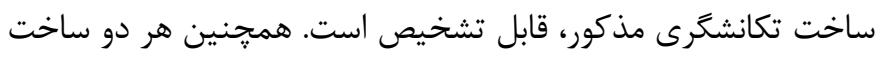

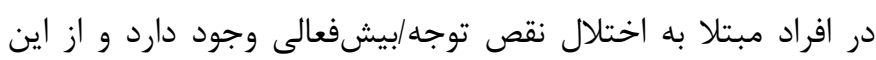

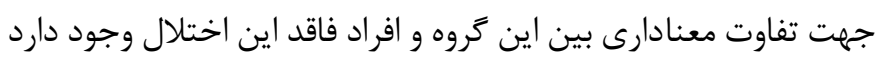
اما شواهد يزوهشى متناقضى در اين زمينه وجود دارد كه نشانكر نياز به يزوهشهاى بيشتر در اين حوزه است. با توجه به اينكه تكانشكرى يكى از مشخصههاى اصلى اين اختلال محسوب مىشود، با مشخص شدن تفاوتهاى دو كروه در مورد ساختهاى مختلف تكانشكرى، درمان كران مى توانند برنامههاى درمانى دقيقترى براى درمان و كنترل

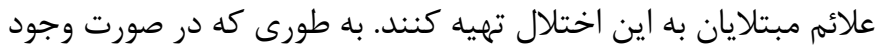

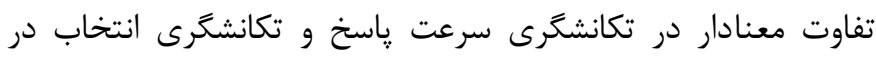
دو كروه (وجود هر دو ساخت تكانشكرى در افراد مبتلا به اختلال

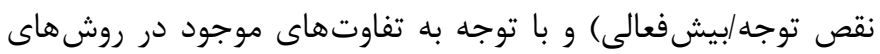
سنجش آنها، قرار دادن فرآيند سنجش و درمان جداءانه براى هر كدام از ساخت هاى تكانشكَى مذكور در برنامه درمانى مى تواند حائز اهميت باشد. همجنين در حوزه درمان اين اختلال، توانبخشى شناختى يكى

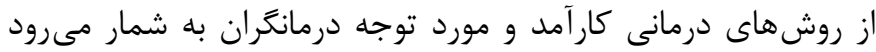

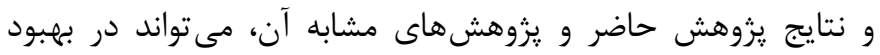

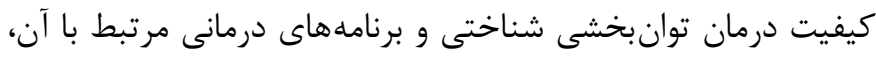

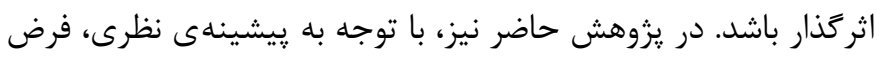

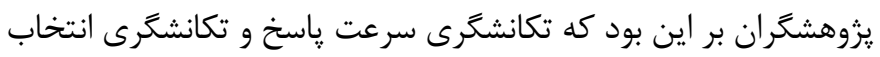

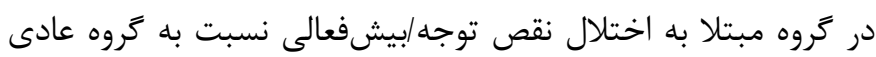

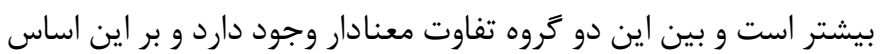
اين دو تروه در اين زمينه مورد مقايسه قرار ترفتهاند.

\section{دوش كار}

در يزوهش حاضر، از روش على_مقايسهاى براى بررسى تفاوت بين

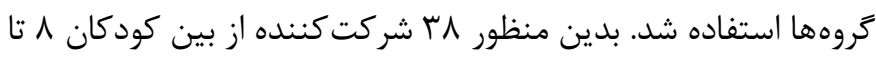

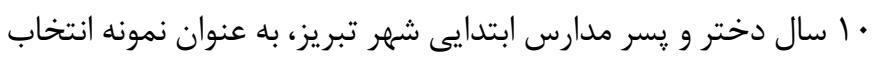

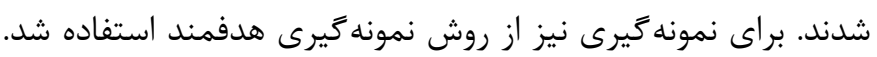

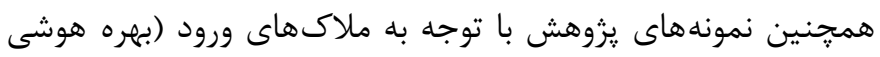

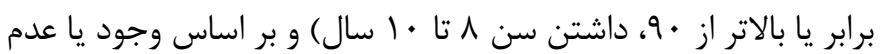
وجود علائم اختلال نقص توجه/بيشفنعالى (با توجه به نتايج مقياس Conners داراى اختلال نقص توجه/بيشفعالى (19 نفر) و كروه كودكان عادى 
بين دسترسى فورى و بدون تاخير به يك بازى رايانهاى براى مدت

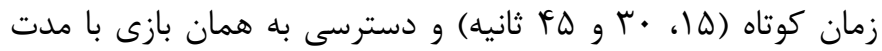

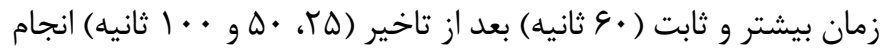

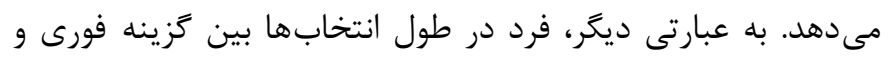

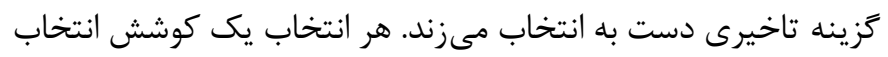

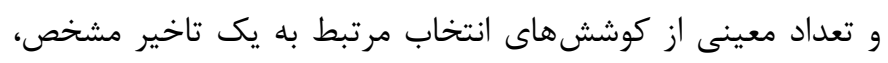

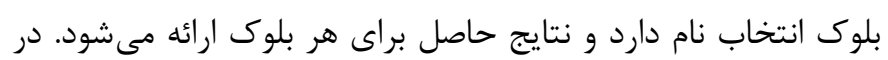
اين تكليف ץ بلوك (تاخير) و در هر بلوك r كوشش انتخاب وجود دارد. زمانهاى بازى ذكر شده در كزينه فورى نيز، در طول هر بلوك از كمترين به بيشترين زمان ارائه مىشود و ترتيب ارائه زمان هاى تاخير در ززينه تاخيرى، در بين شركت كنندًان موازنهسازى مى شود. صرف

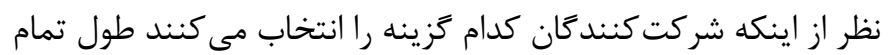

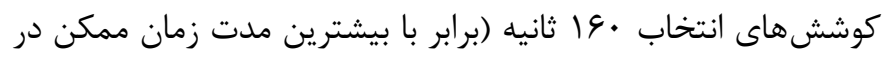

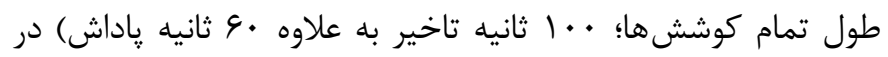

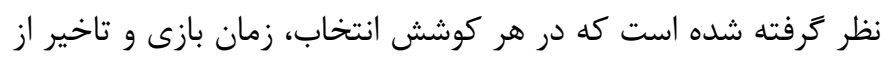

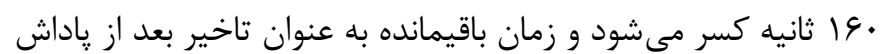

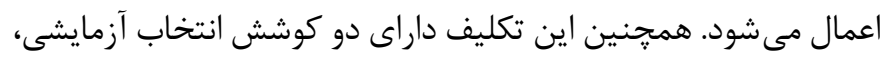

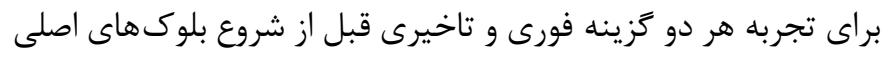
است. خروجى اصلى حاصل از اين تكليف، نقطهى همسانى است (1) (1). به طور كلى، دو روش براى محاسبه نقطه همسانى وجود دارد. اولين و متداولترين روش، محاسبه ميانكين ميزان پاداشهاى فورى انتخاب

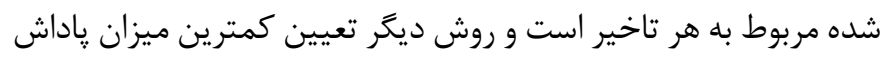

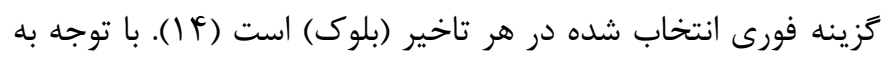

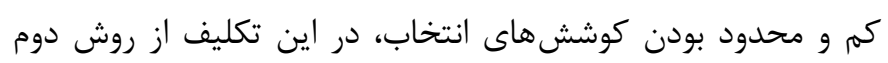
براى محاسبه نقطهى همسانى استفاده شد (F (1)، 9؟).

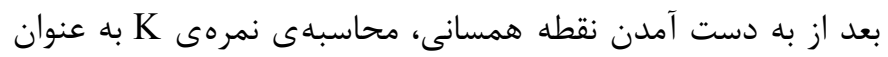

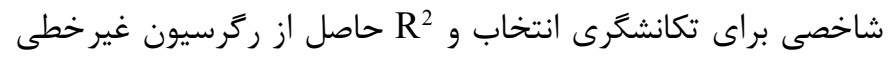
براى برازندگى ميزان كاهش ارزش، روش رايج محاسبات كاهش ارزش تاخيرى است. اما استفاده از ركرسيون غيرخطى مى تواند براى

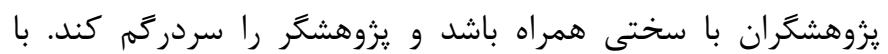

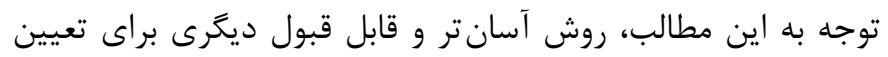

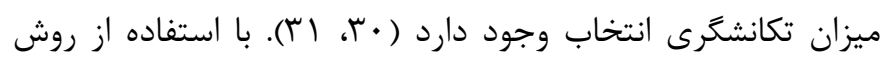
تعيين مساحت زير منحنى (Area under the curve (AUC)) نيز

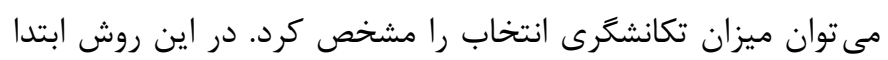
منحنى رسم شده، سيس مساحت جداكانه بين هركدام از تاخيرها در زير نمودار كاهش ارزش، محاسبه و سيس مجموع اين مساحتها بها به عنوان نمره AUC در نظر گرفته مى شود.
4 خرده مرحله است تا تغييرات رفتارى و عملكرد آزمودنى در طول

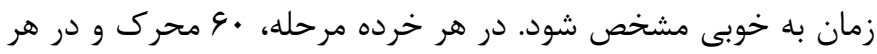

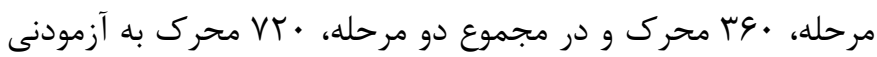

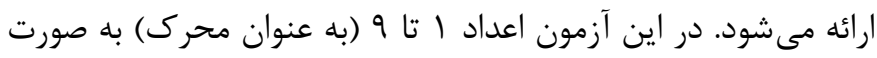

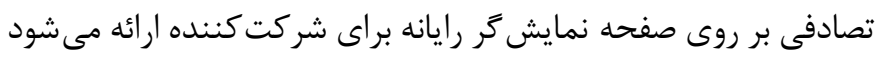

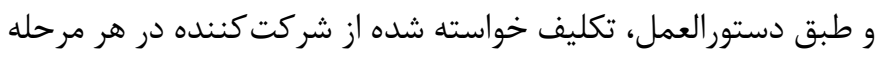
اين است كه بعد از ارائه و مشاهده اعداد ا تا 9 بر روى صفحه نمايشكر، دكمه مشخص شده (كليد فاصله) بر روى صفحه كليد فشار داده شود

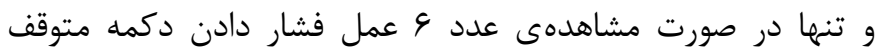
شود. در مرحله دوم، تكليف آزمودنى اندكى رِيجيدهتر مى شود. بدين ترتيب كه در اين مرحله نيز آزمودنى با ديدن تمام محرك ها (اعداد النها

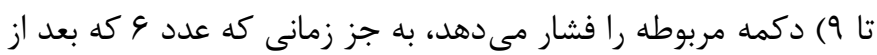
عدد ^ ارائه شده است. در اصل در اين مرحله عدد ^ به عنوان عامل

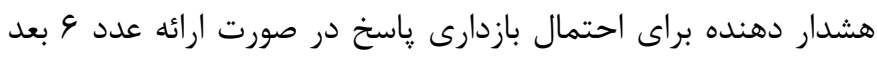

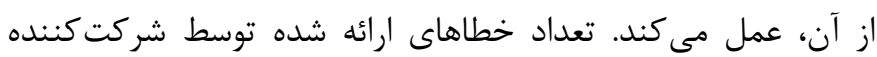

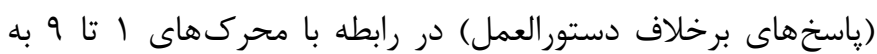
عنوان خطاى حذف و تعداد خطاهاى ارائه شده در رابطه با محرى عدد 9 به عنوان خطاى ياسخ براى هر مرحله و خرده مرحله، به صورت خودكار توسط برنامه ثبت مىشود (「ᄉ). با توجه به اينكه تعداد خطاى حذف براى سنجش توجه و تعداد خطاى ياسخ براى سنجش بازدارى

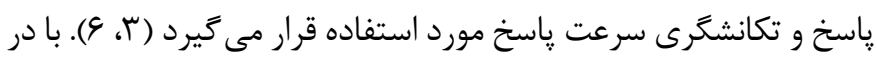
نظر كرفتن موضوع و هدف، در يزوهش حاضر تنها تعداد خطاى ياسخ

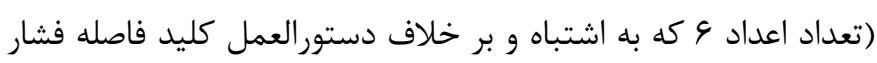

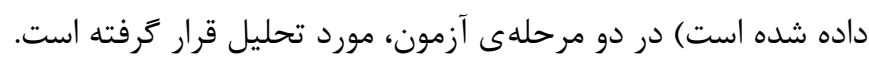
تكليف كاهش ارزش تاخيرى زمان واقعى: اين تكليف، يكى از داز تكاليف رايانهاى روش كاهش ارزش تاخيرى براى سنجش تكانشكرى انتخاب است كه توسط Rosch و Mostofsky در سال 91 • ז، ارائه

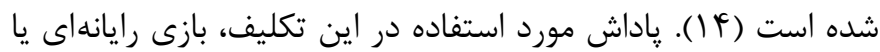
كارتون (بر اساس تمايل كودى) است كه يك پِاداش واقعى و قابل مصرف فورى است. تاخيرها نيز به شكل واقعى توسط كودى تجر تجربه

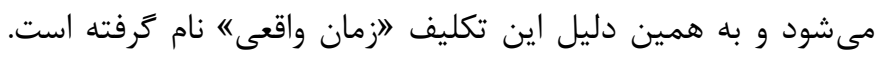

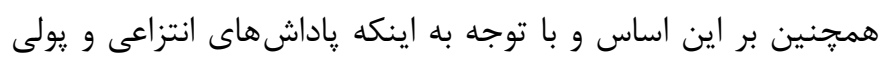

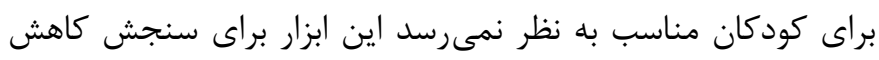

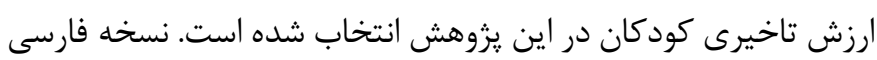
اين تكليف نيز، توسط يزوهشكَ بر اساس الكَى Rosch و Mostofsky طراحى و توسط يك عصبشناس تاييد شده و در اين بزوهش مورد استفاده قرار كرفت. در طول انجام تكليف، شركت كنندكان 9 انتخاب نابن 


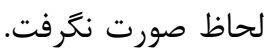
با استفاده از نقطهى همسانى حاصل از تكليف كاهش ارزش تاخيرى،

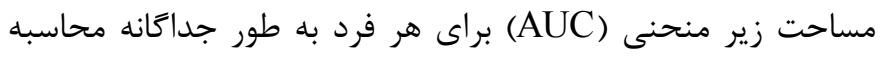

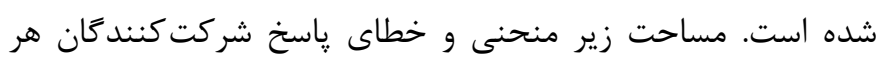

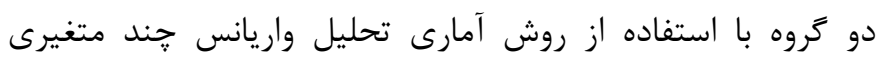
و نرمافزار SPSS-20 مورد مقايسه و تجزيه و تحليل (MANOVA)

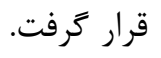

\section{يافته ها}

ميانگين سن و هوش در گروه كودكان مبتلا به اين اختلال به ترتيب

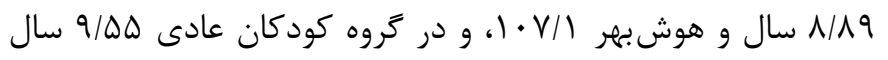

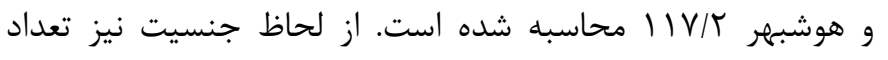

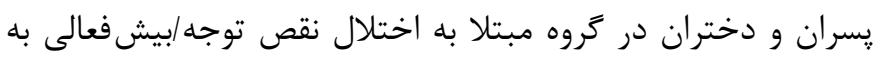

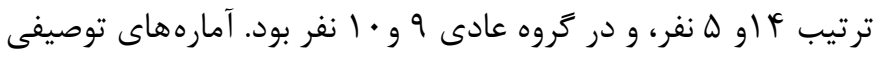
متغيرهاى يزوهش در جدول ا خزارش شده است.
براى محاسبه مساحت زير منحنى از فرمول زير استفاده شده است: $\mathrm{AUC}=\sum\left(\mathrm{x}_{2}-\mathrm{x}_{1}\right)\left[\mathrm{y}_{1}+\mathrm{y}_{2} / 2\right]$

Sمتر نشانكر تكانشكرى انتخاب بيشتر است. با وجود اينكه استفاده از AUC داراى محدوديت هايى است اما روش مناسبى براى تئن

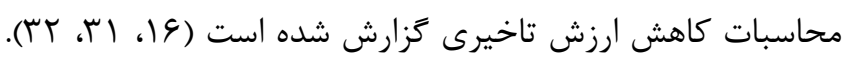

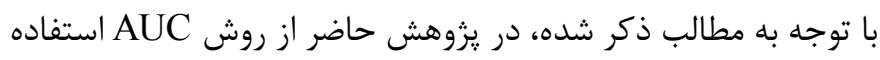

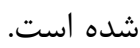
روش اجرا: براى انجام اين يزوهش، يس از بر برسى ملاك هاى ورود و

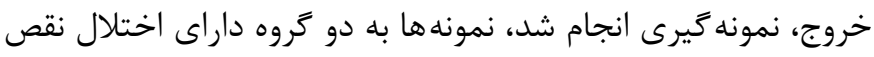
توجه/بيشفعالى و گروه عادى(فاقد اين اختلال) گروهبندى شدند.

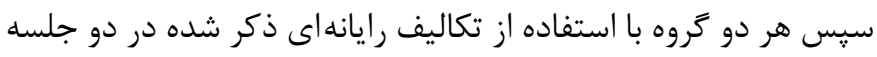
جداكانه مورد سنجش و ارزيابى قرار كرفتند و ترتيب ارائه تكاليف

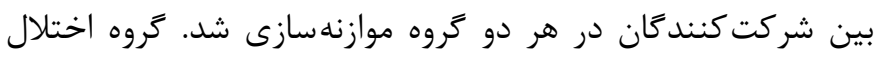

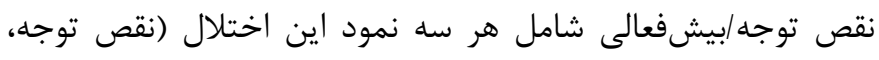

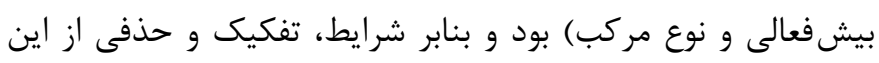

جدول ا. آمار0هاى توصيفى متغيرها

\begin{tabular}{|c|c|c|c|}
\hline 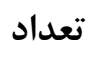 & ميانگين +انحراف استاندارد & تروه & متغير \\
\hline 19 & $\mid \varepsilon / F V \pm V / V F$ & 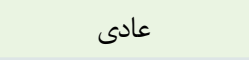 & \multirow{2}{*}{ تعداد خطاى ياسخ } \\
\hline 19 & $r \Delta / \Lambda V \pm q / q \uparrow$ & نقصتوجه/بيشفعالى & \\
\hline 19 & 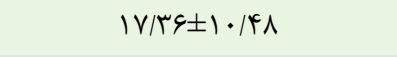 & 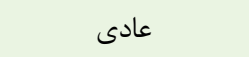 & \multirow{2}{*}{ تعداد خطاى ياسخ } \\
\hline 19 & $r N / \Delta \cdot \pm q / r r$ & نقص توجه/بيشفعالى & \\
\hline 19 & $\cdot \mid \Delta 9 \pm \cdot / 11$ & 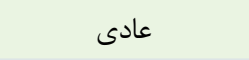 & \multirow{2}{*}{ مساحت زير منحنى } \\
\hline 19 & $\cdot|\Delta q \pm \cdot / 1|$ & نقص توجه/بيشفعالى & \\
\hline
\end{tabular}

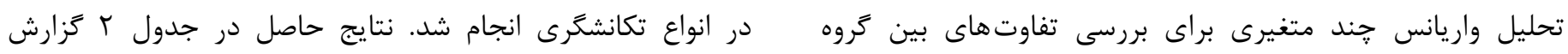

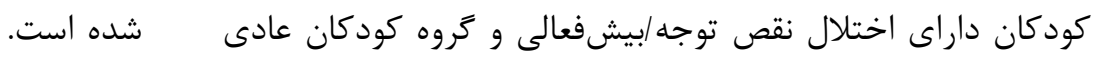

مجذور اتاى تفكيكى

$\cdot / T V$ $\cdot / \cdot 1 \mathrm{~V}$

r/qF
ارزش

كروه $\cdot / V T$

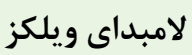


بين دو گروه تفاوت معنادار وجود داشت (P> | IV). با توجه به ميانگين دادهها كه در جدول ا ذكر شده است، در هر دو مرحله آزمون گروه كودكان داراى اختلال نقص توجه/بيشفعالى تعداد خطاى ياسخ بيشترى نسبت به گروه كودكان عادى نشان دادهاند.

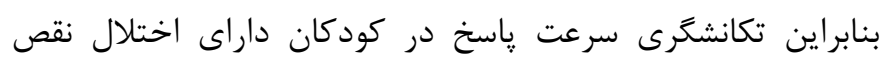
توجه/بيشفعالى نسبت به كودكان عادى بيشتر است و فرضيه اول يزوهشگر تاييد شد.
با توجه به مندرجات جدول فوق، بين دو گروه در متغير وابسته تركيبى تفاوت معنادار وجود داشت (ه •|• همجنين نتايج متغيرهاى وابسته تكانشخرى سرعت پاسخ و و تكانشگرى انتخاب به طور جداگانه در نظر گرفته شد و به ترتيب در جداول ب و أ ززارش شده است. بر اساس نتايج و با استفاده از سطح آلفاى تعديل شده بن فرنى IV • • • در خطاى پاسخ مرحله اول و دوم آزمون عملكرد ييوسته

جدول r. نتايج متغير تكانشَّى سرعت پِاسخ

\begin{tabular}{|c|c|c|c|}
\hline مجذور اتاى تفكيكى & $\mathbf{P}$ & $\mathbf{F}$ & كروه \\
\hline$\cdot / \pi$ & $\cdot / \cdot r$ & $9 / \wedge \wedge$ & تعداد خطاى ياسخ در مرحله اول \\
\hline$\cdot /$ kF & $\cdot / \cdot r$ & $1 \cdot / v 9$ & تعداد خطاى ياسخ در مرحله دوم \\
\hline
\end{tabular}

جدول f. نتايج متغير تكانشكَى سرعت پاسخ

مجذور اتاى تفكيكى

$\cdot / \cdot r$ $\cdot / 4$
F

- Ar
كرو

مساحت زير منحنى
سنجش و بررسى قرار گرفته است. بر اساس يافته هاى يزوهش، در دو

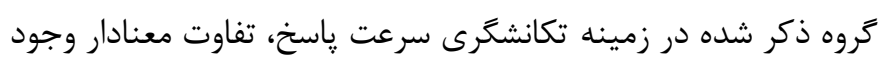
دارد اما در زمينه تكانشخرى انتخاب تفاوت معنادارى مشاهده نشده است. به عبارتى فرضيه اول يزوهش تاييد و فرضيه دوم يزوهش رد شده است. در نظريه Barkley، هسته اصلى اختلال نقص توجه/بيشفعالى ئى وجود نقص در بازدارى ياسخ است (س世). با توجه به اينكه تكانشخرى سرعت پاسخ حاصل نقص در بازدارى ياسخ است، از اين حيث تاييد فرضيه اول يروهش، از لحاظ نظرى قابل تبيين است و اين يزوهش نيز مانند يزوهش هاى همسو وجود تكانشخرى سرعت ياسخ بيشتر در اين اختلال را تاييد مى كند. در رابطه با تكانشگرى انتخاب، نتايج يزوهش برخلاف ييشينه نظرى و نتايج برخى از يزوهشها است. با توجه به اينكه برخى از يزوهشگران علت تناقض در ريشينه يزوهشى اين متغير را عدم ارائهى تاخير بعد

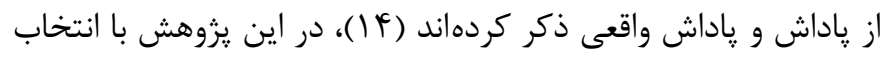

در ادامه نتايج، در مساحت زير منحنى (AUC) حاصل از آزمون كاهش ارزش تاخيرى، بين دو گروه تفاوت معنادار مشاهده نشد (P> • | IV) مساحت زير منحنى، تفاوت معنادارى بين دو گروه در تكانشگرى انتخاب مشاهده نشد و فرضيه دوم يزوهشگر تاييد نشد.

هحث

اين يزوهش با هدف مقايسه تكانشخُى سرعت ياسخ و تكانشخرى انتخاب در كودكان مبتلا به اختلال نقص توجه/بيشفعالى و كودكان

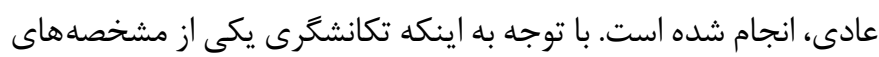
اصلى اختلال نقص توجه/بيشفعالى است، بررسى وضعيت ساخت هاى

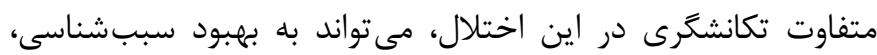
سنجش و درمان اين اختلال كمك كند. بنابراين، در يزوهش حاضر نيز دو ساخت متفاوت تكانشگرى در اقراد مبتلا به اين اختلال مورد 
رد فرضيه يزوهش در رابطه با تكانشكرى انتخاب و عدم وجود تفاوت معنادار در گروهها در اين زمينه، شايد سنجش و درمان اين ساخت

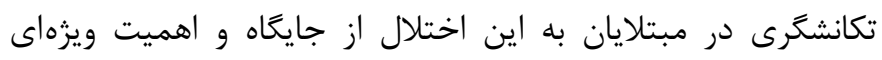

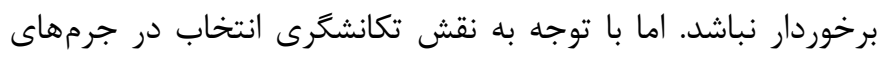

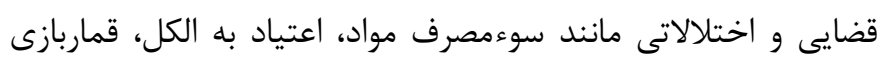

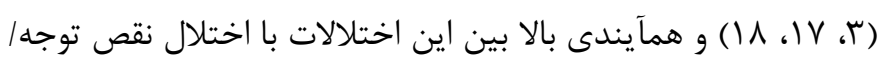
بيشفعالى، سنجش و درمان اين نوع از تكانشكرى در فرآيند درمان

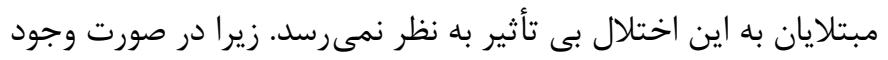
تكانشكرى انتخاب در اين افراد، احتمال ابتلا به اختلالات همآيند ذكرشده تقويت مى شود و شرايط بالينى بيجيدهترى ايجاد مى كند كه إنها

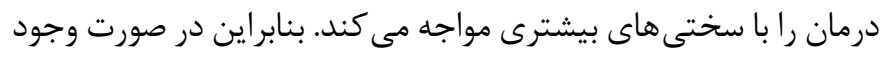

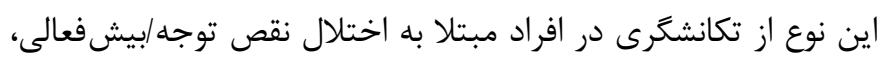

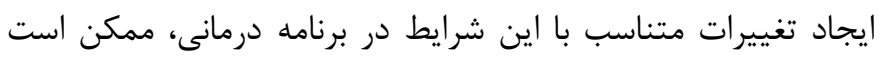
تأثير مثبتى در فرآيند درمان داشته باشد.

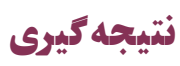

به طور كلى، يُوهشهاى مرتبط با تكانشكرى سرعت ياسخ، بدنه اصلى

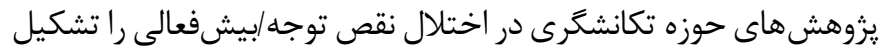
مى دهند در صورتى كه تكانشكَى انتخاب كمتر مورد توجه قرار كرفته است. همجنين بر اساس نظر يروهشگر، بررسى اين دو ساخت در يك

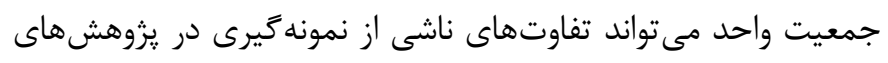

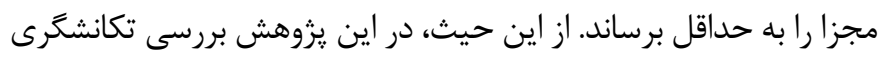

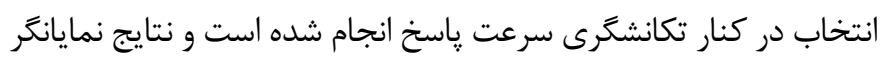

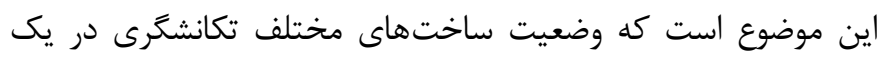

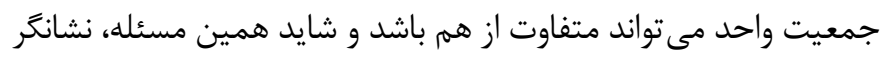

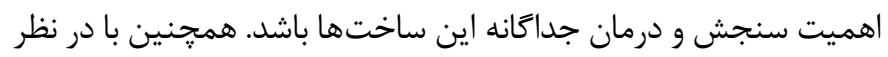

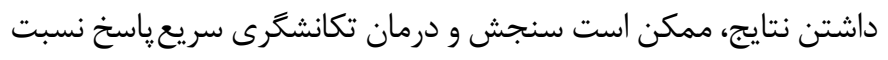

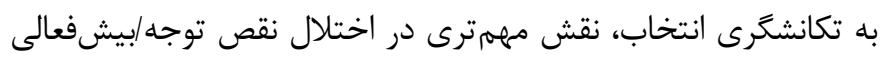

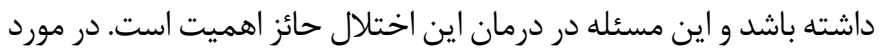

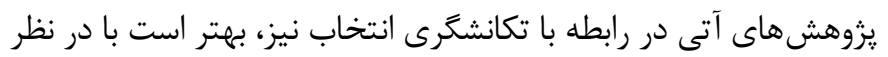

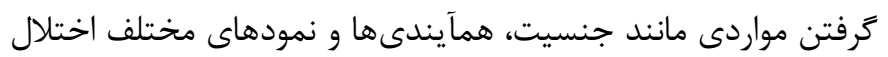

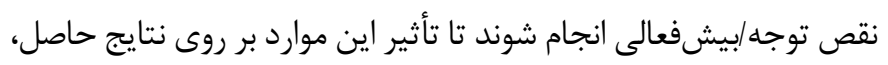

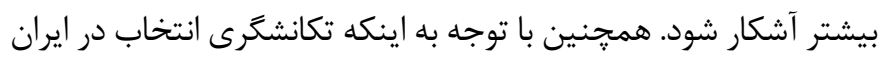

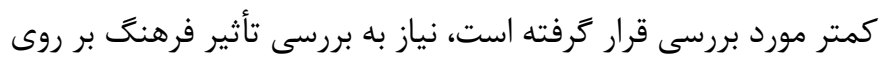

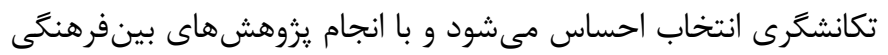

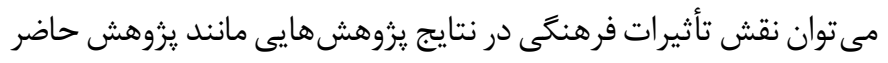

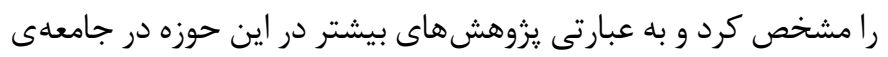

تكليف مناسب، اين دو مورد مدنظر قرار گرفته و هر دو مورد توسط شركت كنند

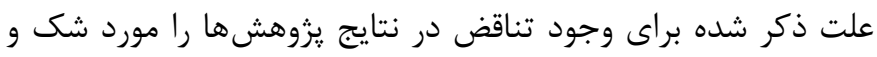

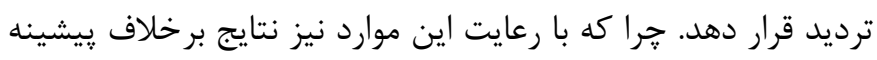

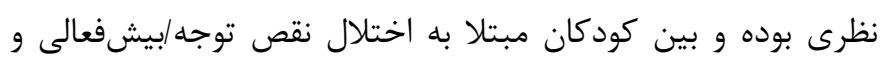
كودكان عادى در تكانشكرى انتخاب تفاوت معنادارى مشاهده نشد.

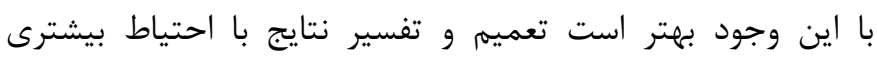

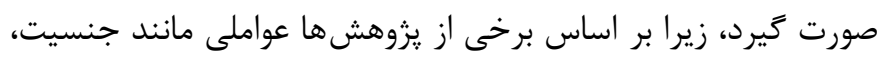

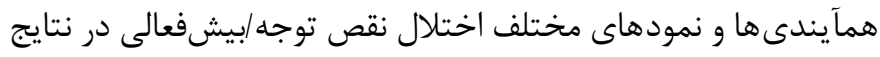

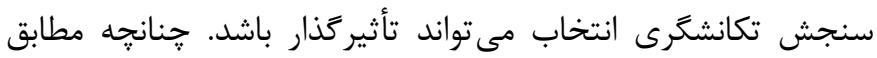
با بيشينه يزوهشى ذكر شده، در يزوهشى كه تكليف كاهش ارزش

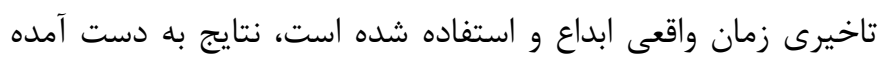

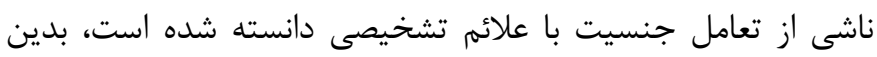

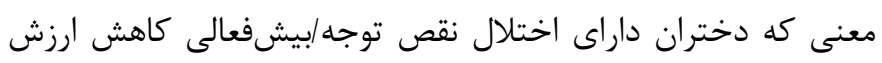

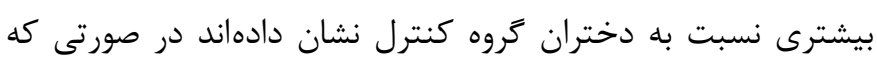

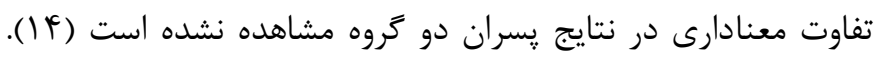

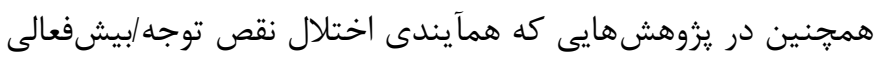
با علايم قماربازى و اوتيسم مد نظر قرار كرفته است، نقش همآيندى ها در افزايش تكانشكرى انتخاب كزارش شده است. به طورى كه تفاوت

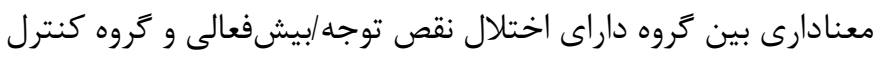

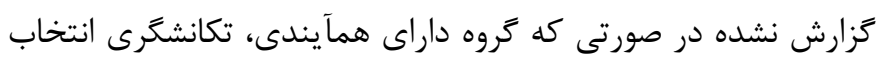

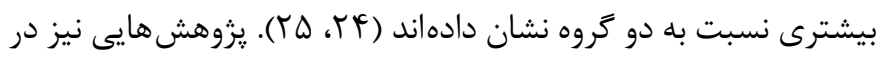

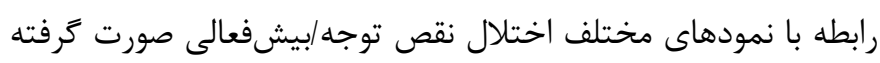
است كه تفاوت تكانشگرى انتخاب در نمودهاى مختلف اين اختلال

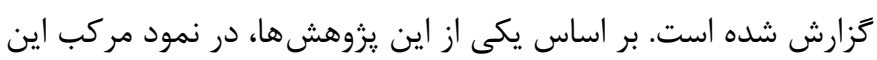

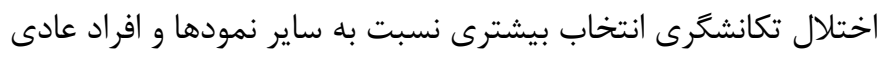

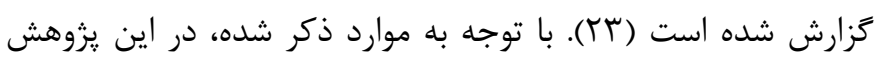

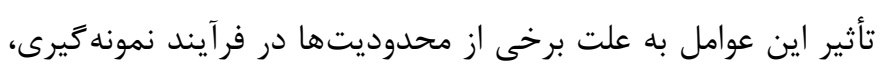

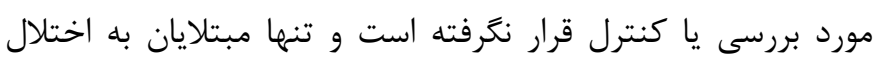

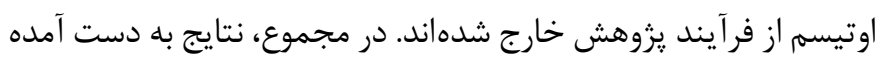

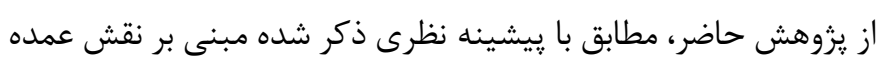

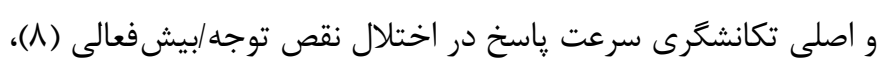

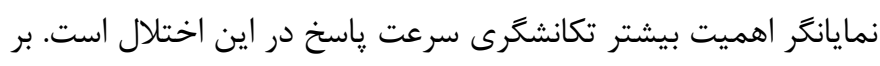

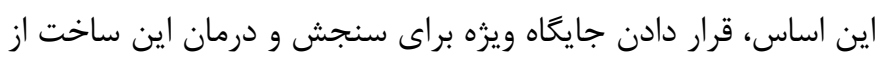

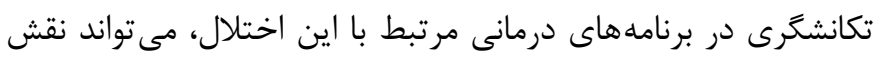

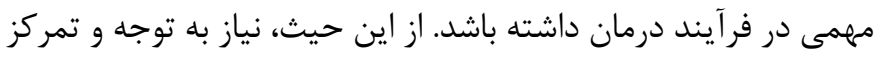

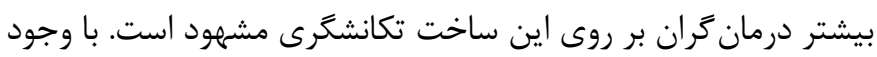


دانشكده علوم تربيتى و روانشناسى دانشگاه تبريز استخراج شده است. نويسندكان بر خود لازم مى دانند از مديريت كل آموزش و يرورش استان آذربايجان شرقى به جهت صدور مجوزهاى لازم براى

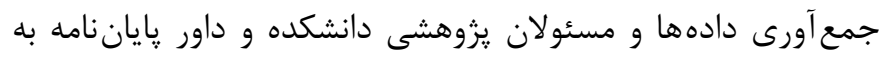
جهت يارى رساندن در ارتقاء كيفى يزوهش تشكر و قدردانى نمايند.

\section{References}

1. American Psychiatric Association. Diagnostic and statistical manual of mental disorders (DSM-5®): Arlington:American Psychiatric Pub;2013.

2. Hamilton KR, Mitchell MR, Wing VC, Balodis IM, Bickel WK, Fillmore M, et al. Choice impulsivity: Definitions, measurement issues, and clinical implications. Personality Disorders: Theory, Research, and Treatment. 2015;6(2):182-198.

3. Patros CH, Alderson RM, Kasper LJ, Tarle SJ, Lea SE, Hudec KL. Choice-impulsivity in children and adolescents with attention-deficit/hyperactivity disorder (ADHD): A meta-analytic review. Clinical Psychology Review. 2016;43:162-174.

4. Bari A, Robbins TW. Inhibition and impulsivity: Behavioral and neural basis of response control. Progress in Neurobiology. 2013;108:44-79.

5. Chamberlain SR, Fineberg NA. Fractionating impulsivity: Commentary on "choice impulsivity" and "rapid-response impulsivity" articles by Hamilton and colleagues. Personality Disorders. 2015;5(2):201-203.

6. Hamilton KR, Littlefield AK, Anastasio NC, Cunningham KA, Fink LH, Wing VC, et al. Rapid-response impulsivity: Definitions, measurement issues, and clinical implications. Personality Disorders: Theory, Research, and Treatment. 2015;6(2):168-181.

7. Winstanley CA, Eagle D M, Robbins TW. Behavioral models of impulsivity in relation to ADHD: Translation between clinical and preclinical studies. Clinical Psychology Review. 2006;26(4):379-395.

8. Wodka EL, Mark Mahone E, Blankner JG, Gidley Larson

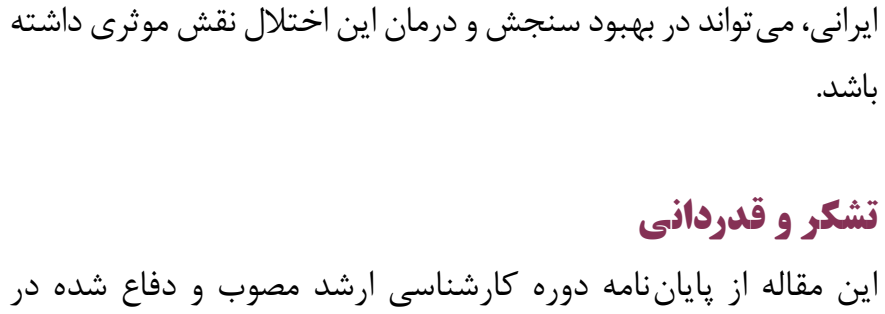

JC, Fotedar S, Denckla MB, et al. Evidence that response inhibition is a primary deficit in ADHD. Journal of Clinical and Experimental Neuropsychology. 2007;29(4):345-356.

9. Moeller FG, Barratt ES, Dougherty DM, Schmitz JM, Swann AC. Psychiatric aspects of impulsivity. American Journal of Psychiatry. 2001;158(11):1783-1793.

10. Alderson RM, Rapport MD, Hudec KL, Sarver DE, Kofler MJ. Competing core processes in attention-deficit/hyperactivity disorder (ADHD): Do working memory deficiencies underlie behavioral inhibition deficits?. Journal of Abnormal Child Psychology. 2010;38(4):497-507.

11. Tehrani Doust M, Rad Goudarzi R, Sepasi M, Alaghband Rad J. Executive functions in children with attention deficit hyperactivity disorder. Advances in Cognitive Sciences. 2003;5(1):1-9. (Persian)

12. Crunelle CL, Veltman DJ, Van Emmerik-Van Oortmerssen K, Booij J, Van Den Brink W. Impulsivity in adult ADHD patients with and without cocaine dependence. Drug and Alcohol Dependence. 2013;129(1-2):18-24.

13. Barkley RA, Edwards G, Laneri M, Fletcher K, Metevia L. Executive functioning, temporal discounting, and sense of time in adolescents with attention deficit hyperactivity disorder (ADHD) and oppositional defiant disorder (ODD). Journal of Abnormal Child Psychology. 2001;29(6):541-556.

14. Rosch KS, Mostofsky SH. Increased delay discounting on a novel real-time task among girls, but not boys, with ADHD. Journal of the International Neuropsychological Society. 2016;22(1):12-23. 
15. Orsini CA, Mitchell MR, Heshmati SC, Shimp KG, Spurrell MS, Bizon JL, et al. Effects of nucleus accumbens amphetamine administration on performance in a delay discounting task. Behavioural Brain Research. 2017;321:130-136.

16. Odum AL. Delay discounting: I'm a k, you're a k. Journal of the Experimental Analysis of Behavior. 2011;96(3):427-439. 17. Bulley A, Gullo MJ. The influence of episodic foresight on delay discounting and demand for alcohol. Addictive Behaviors. 2017;66:1-6.

18. Lee CA, Derefinko KJ, Milich R, Lynam DR, DeWall $\mathrm{CN}$. Longitudinal and reciprocal relations between delay discounting and crime. Personality and Individual Differences.2017;111:193-198.

19. Reynolds B, Schiffbauer R. Measuring state changes in human delay discounting: An experiential discounting task. Behavioural Processes. 2004;67(3):343-356.

20. Angott AM. What causes delay discounting? [PhD Dissertation]. Michigan:University of Michigan;2010.

21.Taj M, Mokri A, Fotohi A. Delay discounting (DD) in correlation with time perspective in medical interns. Iranian Journal of Psychiatry and Clinical Psychology. 2005;11(3):327334. (Persian)

22. Wilson VB, Mitchell SH, Musser ED, Schmitt CF, Nigg

JT. Delay discounting of reward in ADHD: Application in young children. Journal of Child Psychology and Psychiatry. 2011;52(3):256-264.

23. Scheres A, Tontsch C, Thoeny AL, Kaczkurkin A. Temporal reward discounting in attention-deficit/hyperactivity disorder: The contribution of symptom domains, reward magnitude, and session length. Biological Psychiatry. 2010;67(7):641-648.

24. Dai Z, Harrow SE, Song X, Rucklidge JJ, Grace RC. Gambling, delay, and probability discounting in adults with and without ADHD. Journal of Attention Disorders. 2016;20(11):968-978.
25. Chantiluke K, Christakou A, Murphy CM, Giampietro V, Daly EM, Ecker C, et al. Disorder-specific functional abnormalities during temporal discounting in youth with attention deficit hyperactivity disorder(ADHD), Autism and comorbid ADHD and Autism. Psychiatry Research: Neuroimaging. 2014;223(2):113-120.

26. Scheres A, Dijkstra M, Ainslie E, Balkan J, Reynolds B, Sonuga-Barke E, et al. Temporal and probabilistic discounting of rewards in children and adolescents: Effects of age and ADHD symptoms. Neuropsychologia. 2006;44(11):2092-2103.

27. Conners' CK. Conners' Rating Scales-Revised: Technical manual. North Tonawanda, NY:Multi-Health Systems Inc; 1997.

28. Conners' CK, Staff MHS. Conners' continuous performance test (CPT II) computer programs for windows technical guide and software manual. North Tonawanda, NY:Multi-Health Systems Inc;2000.

29. Ekhtiari H, Behzadi A, Jannati A, Moghimi A. Delayed discounting procedure and impulsive behaviors: A preliminary study. Advances in Cognitive Sciences. 2003;5(2):46-55. (Persian)

30. Johnson MW, Bickel WK. An algorithm for identifying nonsystematic delay-discounting data. Experimental and Clinical Psychopharmacology. 2008;16(3):264-274.

31. Reed DD, Kaplan BA, Brewer AT. A tutorial on the use of Excel 2010 and Excel for Mac 2011 for conducting delay discounting analyses. Journal of Applied Behavior Analysis. 2012;45(2):375-386.

32. Myerson J, Green L, Warusawitharana M. Area under the curve as a measure of discounting. Journal of the Experimental Analysis of Behavior. 2001;76(2):235-243.

33. Barkley RA. Behavioral inhibition, sustained attention, and executive functions: Constructing a unifying theory of ADHD. Psychological Bulletin. 1997;121(1):65-94. 